\title{
A Communication Pattern of President in Infrastructure Development : The Case of Jokowi in The Daily Kompas
}

\section{News}

\author{
Suharyo Suharyo ${ }^{1 *}$ \\ ${ }^{1}$ Indonesian Department,Faculty of Humanities, Diponegoro University, Semarang 50275, Indonesia
}

\begin{abstract}
This study aims to describe the daily frame of Kompas against President Joko Widodo. Data was excavated from Kompas daily news published in 2016/2017 using referring method and record technique. Data analysis was done by using framing analysis of Pan and Kosicki model. The result, (1) from the schematic element: Golkar's decision to nominate Joko Widodo as presidential candidate in 2019 proves that Golkar is in a state of cadre crisis and fails, (2) from the script elements: Golkar does not have a great cadre, (3) from thematic elements: (b) Golkar Party "always fails" to deliver its cadres to become RI-1, (c) Golkar can not be separated from the "shackles" of government / power, (d) Golkar has no cadres, ) Golkar has a "curse", (e) there is an error in the regulatory system in Golkar, (f) Golkar is playing srtategy with Joko Widodo's nomination, (g) power-hungry Golkar, and (h) Golkar, as a big party, is very unfortunate because it can not play its role to determine the national political constellation; and (4) from the rhetorical element: sentences that are used are "meaningless".
\end{abstract}

Keywords: Frame; media; Joko Widodo; framing analysis.

\section{Introduction}

For positivism, journalistic work is objective and impartial in accordance with journalistic principles. Can this normative condition be found in the current era of reformation? Lukmantoro's research results[1] Irfan[2] Hasfi[3] , Rachanca,[4], Windranuari, [5], Atmadja[6], Flora[7] shows that news in the mass media has been constructed in such a way as a political, economic, and sociocultural commodity.This is in line with the critical linguistic view that language choice is made according to a set of political, social, cultural, and ideological constraints. So, (a) the choice of language is not an individual choice but produced by interaction and communication which determined ideologically and politically, and language systems are an integral part of structure and social process, (c) language as a tool for categorizing the realities of life, [8,9]. Masnur Muslich explains that the mass media has a strong and powerful power to construct reality (which was then published as news) [10]

Karman's study indicates that the Ahmadiyah issue for Suara Pembaruan is a matter of human rights / freedom of religion[11], while Republika frames the Ahmadiyya activities as defamation, harassment, deviance, and desecration [12]. Another research conducted by Pamela Prastyana concludes that Solopos Public Daily acknowledges that Joko Widodo has a high news value[13]. Reality is not "actual fact", but has been framed by the author (journalist / editor) in accordance with certain interests (ideology, politics, economy). $[14,15,16]$. From the description above, how is the Kompas daily in framing President Joko Widodo? Is it objective, independent, and mono-interpretation as the views of positivism? Or just the opposite, that is subjective and aligned as a constructionist view?

\section{Method}

This study took data from Kompas Daily News Paper published between 2016-2017. Data collection is conducted by referring to the method followed by note taking techniques. The method of refer is conducted by (1) to carefully read the articles/news about President Jokowi written by reporters (editorial), observers, politicians, and the society in general, (2) examining the structural aspects of the language (word choice, vocabulary sentence, coherence, aspects of reason, etc.), (3) looking at the important things in the form of construction of President Jokowi's reality. This study also uses structured interview methods and in-depth interviews. Interviews were carried out on linguist informants (discourse / framing), communication / politics, and mass media. This method is conducted to find out the views of information according to the field of science. The (temporary) results of this research will then be discussed with experts who are competent in their fields (politics, media, and linguistics). 
In addition to the things above, in this research, a literature study was also conducted. Literature studies were conducted to collect all the materials relevant to this study. For example, the literature on framing analysis, research journals using the framing approach.

\section{Data Analysis}

In this study, data were analyzed using the Pan and Kosicki framing analysis method as shown in the following chart.

The Analysis Framework of Pan and Kosicki's Framing

\begin{tabular}{|c|c|c|}
\hline STRUCTURE & $\begin{array}{l}\text { FRAMING } \\
\text { DEVICES }\end{array}$ & $\begin{array}{c}\text { OBSERVED } \\
\text { UNIT }\end{array}$ \\
\hline $\begin{array}{l}\text { SIKTAKSIS } \\
\text { How Journalists } \\
\text { compile facts }\end{array}$ & 1. News Scheme & $\begin{array}{l}\text { Headlines, } \\
\text { leads, } \\
\text { background } \\
\text { information, } \\
\text { quotes, sources, } \\
\text { statements, } \\
\text { conclusions }\end{array}$ \\
\hline $\begin{array}{l}\text { SCRIPT } \\
\text { How journalists } \\
\text { tell the facts }\end{array}$ & $\begin{array}{l}\text { 2. The News } \\
\text { Completeness }\end{array}$ & $5 \mathrm{~W}+1 \mathrm{H}$ \\
\hline $\begin{array}{l}\text { THEMATIC } \\
\text { How journalists } \\
\text { write the facts }\end{array}$ & $\begin{array}{l}\text { 3. Details } \\
\text { 4. Coherence } \\
\text { 5. Sentence } \\
\text { Form } \\
\text { 6. Word Change }\end{array}$ & $\begin{array}{l}\text { Paragraphs, } \\
\text { propositions, } \\
\text { sentences, } \\
\text { relationships } \\
\text { between } \\
\text { sentences }\end{array}$ \\
\hline $\begin{array}{l}\text { RHETORICAL } \\
\text { How journalists } \\
\text { emphasize facts }\end{array}$ & $\begin{array}{l}\text { 7. Leksikon } \\
\text { 8. Grafis } \\
\text { 9. Metafora }\end{array}$ & $\begin{array}{l}\text { Words, idioms, } \\
\text { pictures / } \\
\text { photos, graphics }\end{array}$ \\
\hline
\end{tabular}

\section{Result and Discussion}

This research takes the data source from Kompas which published in 2016/2017. The data were collected by the method of recall and technique of note, while the analysis used framing analysis model of Pan and Kosicki [17]

Kompas failed at framing and curses against Golkar Party, as presented in table 1 below.

Table 1. Frame of Joko Widodo by Kompas

\begin{tabular}{|c|l|}
\hline \multicolumn{1}{|c|}{ Element } & \multicolumn{1}{c|}{ Writing Strategy } \\
\hline Schematic & $\begin{array}{l}\text { The Golkar Party's decision to } \\
\text { nominate Joko Widodo as a } \\
\text { presidential candidate in 2019 } \\
\text { proves that Golkar Party is in a } \\
\text { state of cadre crisis and a } \\
\text { "condemnation" of the RI-1 } \\
\text { seats because the Golkar party } \\
\text { failed to make Akbar Tanjung, }\end{array}$ \\
\hline
\end{tabular}

\begin{tabular}{|l|l|}
\hline Wiranto and Aburizal Bakri \\
become the president of \\
Indonesia. It cam be read from \\
the title "Golkar Party Supports \\
Joko Widodo Ana "Curse" of \\
Kursi RI-1" because Golkar \\
Party always failed to make its \\
cadres as President of RI.
\end{tabular}

\section{Conclusion}

Kompas failed the frame and curse against the Golkar Party. From this last frame, Kompas made a news about the failure of the Golkar Party in the cadre. Therefore, Golkar Party always failed to make its cadres become RI-1. This is because the cadre system insiden the Golkar Party is not running. In addition, it is unfortunate that some parties, as large as Golkar, are unable to give color in the political constellation at the national level. 
Therefore, Golkar Party should be "cursed". Due to these failures, the Golkar Party finally nominated Joko Widodo as a presidential candidate in 2019. It is interpreted as the Golkar Party's failure to organize its cadres, but on the other hand Golkar Party is "hungry for power", and depends heavily on government. In one of his programs, Joko Widodo was forest conservation, biautaut, and utilization of waste.

\section{References}

1. T.Lukmantoro, Ahmadiyyah Discourse in Mass Media (Discourse Analysis Daily Voice Suara Merdeka in Case of Attack against Ahmadiyah Jama'at Indonesia in Cikeusik, Pandeglang, Banten). Unpublished Thesis. Diponegoro University, Semarang (2011).

2. N.Irfan. Framing Daily News Reporting Kompas on Ruuk-Diy. Unpublished Thesis. Diponegoro University, Semarang.(2011)

3. N.Hasfi, Nurul Framing Reporting Analysis Malinda Dee at Detikcom Tempo Magazine And Metro TV. Unpiblished Thesis Diponegoro University, Semarang. (2011).

4. M.Rachanca. Framing Kompas and Republika's Newspaper against the Israeli-Palestinian War Event. Unpublished Thesis. Diponegoro University, Semarang (2012)

5. S.Windranuari. Framing of Kompas and Suara Merdeka Concerning the Controversy of Century Bank Bailout (Bail Out) of Century Bank (Analysis of Framing of Preaching of Kompas and Suara Merdeka), Diponegoro University, Semarang (2010).

6. X.L.Atmadja. Framing Analysis of the coverage of Basuki Tjahaja Purnama (Ahok) in Media Online. Petra Christian University, Surabaya.(2014)

7. E.Flora.Framing Analysis News Presidents of the Republic of Indonesia 2014 - 2019 On Newspapers Kaltim Post and Tribun Kaltim. Unpublished
Thesis. Mulawarman University, East Kalimantan. (2014).

8. Y.A.Darma. Critical Discourse Analysis, Yrama Widya, Bandung (2013).

9. B.Lee. The Power Principle (Translation Alfin Saputra), Bina Putra Aksara, Jakarta (2002).

10. M.Muslih. Journal of Languages and Arts 36 no.2. The Power of Mass Media Constructs Reality. (2008).

11. Karman. Communication and Media Studies Journal, Vol.17. Mass Media and Construction of Reality (Framing Analysis of Newsletters on Ahamdiyah in Indonesia in the Suara Pembaruan and Republika Daily Newspapers. (2013).

12. N.Irfan. Framing Daily News Reporting Kompas on Ruuk-Diy..Unpublished Thesis. Diponegoro University, Semarang. (2011).

13. Prastyana, Prastyana. "The Issue of Joko Widodo as Jakarta Governor Candidate in Mass Media (Analysis of News Framing Issue of Issue of Joko Widodo as Jakarta Governor Candidate in Daily Solopos Period October 2011 - March 2012)". Unpublished Essay. Solo: UNS. (2013).

14. Suharyo. "Language and Power: Between Discourse Battles and Power Seeking (Case Studies of Politicians' Behavior in Mass Media". Semarang: Unpublished Research Report of Diponegoro University. (2013).

15. Suharyo. "Language and Ideology: Uncovering the Ideology and Symbolic Strength Behind Language Use (Media Text Review Through Critical Discourse Analysis)". Semarang: Research Report of Diponegoro University. (2014).

16. Suharyo. "Media Construction of President Joko Widodo through Framing Analysis".Semarang: Research Report of Diponegoro University. (2016).

17. Eriyanto Framing Analysis: Construction, Ideology, and Political Media (Cet.ke-3). Yogyakarta: LKIS. (2012). 